\title{
Needs Analysis of Business English Undergraduates and the Implications to Business English Curriculum Design
}

\author{
Juan Li (Corresponding author) \\ School of Foreign Language Studies, Shandong Jiaotong University \\ 250357, Jinan, China \\ E-mail: seija1203@126.com
}

Doi:10.7575/aiac.alls.v.5n.4p.33

URL: http://dx.doi.org/10.7575/aiac.alls.v.5n.4p.33
Received: 10/04/2014

Accepted: 13/06/2014

The research is financed by the Research Base of Humanities and Social Sciences of Shandong Province-International Business Study Center, the Teaching Research Foundation of Shandong Jiaotong University: Curriculum Design for Business English Students Based on Needs Analysis Theory-A Case Study of Shandong Jiaotong University (No. JY201211), and the Scientific Research Foundation of Shandong Jiaotong University (No. R201301).

\begin{abstract}
Needs Analysis is a valuable and irreplaceable tool in the curriculum design of Business English courses. It ensures a focused and efficient curriculum design responsive to the learners' needs. This paper analysis the needs of Business English undergraduates and the information obtained may offer some helpful suggestions to the setting of the teaching goals, selecting textbooks and teaching methods and thus provide reliable guidance for the course designers.
\end{abstract}

Keywords: Needs Analysis, Business English, undergraduates

\section{Introduction}

Business English, as the most important branch of English for Specific Purpose (ESP), shares the typical characteristic of ESP: needs analysis. However, due to the influence of traditional teaching opinions and limited knowledge of Needs analysis Theories, course designers and language teachers in China either neglect needs analysis or cannot carry out it effectively. As a result, Business English teaching in colleges and universities is facing many challenges including optimizing course design, setting teaching goals, updating teaching concepts, training teachers and compiling textbooks. Based on needs analysis theory, this paper tries to analyze the target needs and learning needs of Business English undergraduates with a view to provide a basis for the design and implementation of course contents, fixing of teaching objective and teaching contents, thus provide references for the Business English teaching.

\section{Needs Analysis in Business English Teaching}

As one of the most important branches of ESP (English for Specific Purposes), Business English has nearly sixty years' history in China. After years of research, a battery of objectives of Business English teaching have pinned down by scholars and educators, aiming to equip students with a solid foundation of application-oriented knowledge and skills in both English and business. Such goals have been endorsed by the Ministry of Education, which was highlighted in 2009 in the release of "National Curriculum for BA Program in Business English" (hereafter called National Curriculum), a curriculum design guideline for all colleges and universities in China. In the National Curriculum, four modules of Business English are proposed: English knowledge and skills, Business Knowledge \& Skills, Cross Cultural Communicative Competence and Humanity Knowledge. How to balance the proportion of the four modules according to learners' specific needs worth further research.

Needs analysis refers to "the activities involved in gathering information that will serve as the basis for developing a curriculum that will meet the learning needs of a particular group of students" (Brown, 1995; p.35). A sound needs analysis is of crucial importance to the design of courses and to reevaluate the existing curriculum. During the process of needs analysis, subject and objective information can be obtained from various sources, for examples, questionnaires, interviews, observation, and tests (Pratt, 1980). In this paper, the author will try to determine the Business English learners' perception of the needs by using the questionnaire survey.

In 1987, Hutchinson \& Waters put forward their model of needs analysis. Two concepts, target needs and learning needs are proposed in the model. Target needs refer to the knowledge and skills the learners must master in the future working positions. It can be divided into "necessities", "lacks" and "wants". "Necessities" is shaped by the demands of the target situation, "It is what the learner has to know in order to function effectively in the target situation" (Hutchinson \& Waters, 1987, p.55). "Lacks" refer to the gap between the "existing proficiency of learners" and the "target proficiency of learners". "Wants" are the subjective perception of learners that they want to learn from the language courses. Educators should study the target needs and learning needs of the language learners and tries to satisfy these needs in 
the curriculum design of Business English teaching. Learning needs are what the learners need to do to master the required knowledge and skills. When identifying the learning needs, learners' information such as their interests and background, their knowledge, skills and strategies and their motivation for learning should be considered.

\section{Research Methodology}

\subsection{Introduction}

The methodology employed in the present study is questionnaire survey. The questionnaire is designed according to Hutchinson \& Waters' Model (1987) for needs analysis. The questionnaire includes students' motivation of choosing Business English branch, their learning needs and their self-evaluation of lacks. Each section of the questionnaire serves a unique purpose. The first section tries to inquire into the students' personal information, such as their motivation, attitudes to English. The second section is to find their learning needs such as their evaluation for the current teaching material, their preferred organization form of classes, and their expectation for Business English teachers. The third section is their self-evaluation of the lacks of the four modules and language skills. The aim of questionnaire is to elicit information on their perception of their language needs and wants, their current language lacks, and learning environments.

The questionnaire was completed in normal class time after a detailed instruction is given on how to respond to the questionnaire. The participants took about 15 minutes to answer the questionnaire. All the distributed questionnaires were answered and returned.

\subsection{Participants}

The subjects for learners' needs analysis are 62 third-year English Major students in the Foreign Language Department of Shandong Jiaotong University (SDJTU). They have two years English language related courses and at the end of the fourth term, they were asked to choose to study either Business English or English literature in the following two school years. When answering the questionnaire, they had finished two years language study and one year Business English study. Before distributing the questionnaire, 10 students were randomly chosen to be interviewed to find their concerning questions and the questionnaire was compiled with these questions especially concerned. By the time the study was carried out, most of them had passed TEM4, which indicates that the subjects had reached a certain level of English proficiency. They were familiar with the curriculum design: they had studied basic English courses for two years and Business English courses for one year. The courses they had taken related to Business English are: Advanced Business English, International Marketing, E-Commerce, Market Research, International Trade Theory, Import and Export Practice, International Finance, International Business Law and Correspondence for Import \& Export. The courses should preferably be taught by English language teachers in English with foreign trade background.

\subsection{Data Collection \& Data Analysis}

The questionnaires were distributed in class. All the 61 distributed questionnaires were answered and returned. As the needs analysis was new to students, students had difficulty articulating their needs and understanding what was meant by some questions. Therefore, the author interpreted and explained each item on the questionnaire that might be subject to different interpretations by different students in order to resolve any ambiguity. They were encouraged to come up with suggestions or what they do not understand in the questionnaire.

To ensure that the answers are more close to the real situation, the questionnaire is made anonymous to release the participants' anxiety when they were answering the questionnaires.

\section{Results and Discussion}

\subsection{Motivation}

In the learning process, motivation is a very important factor. Success in learning can only come about if the learner is motivated. (Ellis \& Johnson, 1994). Thus question 1 is designed to find the undergraduates' motivation of choosing Business English direction. The result reveals that a majority of students (60.7\%) of English majors choose "work in the related area", $18 \%$ (11 out of 61 ) of the participants choose "interest", and $6.6 \%$ (4 out of 61 ) choose "attend postgraduate entrance examination". The percentage shows that the aim of the students choosing Business English is mainly to work in the business field and some of them choose the business English branch because of interest. Still there are 9 students, which amounts for $14.8 \%$, choose the item "finish the credit". The author had an interview with those students; the reasons are "to avoid the boring literatures courses" or "no other better choices". This shows that some of the students do not have a clear view of what they will do or even what they like, the deeper reason being that students may not know what the course used for.

Question 2 is about the career plan of junior students. When asked about "Do you have a career plan or career goal after graduation?" Thirty-eight students, which constitutes to $62.3 \%$ of the total participants, choose "yes"; while still $37.7 \%$ of them do not have a clear plan for their future plan.

Bearing in mind the importance of motivation of learners, Brown (1995) suggested that for pedagogical purposes, a distinction should be made between intrinsic and extrinsic motivation. Learners with intrinsic motivation initiate learning activities because of the existence of uncertainty, while learners with extrinsic motivation carry out learning activities due to the desire of obtaining external rewards or avoiding punishment. He thinks that intrinsic motivation tends to lead to more successful learning outcomes by comparison with extrinsic motivations. In question 1, "interest" belongs to intrinsic motivation whereas "work", "pass the exam" or "finish the credit" can be categorized as extrinsic 
motivation. The result of this question shows that only $18 \%$ of the students learn Business English courses because of interest, and $37.7 \%$ of them do not have a clear plan for the future career. To arouse the intrinsic motivation of the students, efforts should be made to help students identify needs in future job. Measures like teachers' showing the students video of real business situations, inviting business practitioner or experts to give lectures, encouraging students to work as part-time interpreters in international conference and pay personal visits to job fairs can help those preexperience learners have a visualized impression of what is Business English and what it is used for thus arouse their interest.

\subsection{Learning needs}

Questions 3-10 are designed to find the learning needs of undergraduates. Question 3 tries to find whether the participants are satisfied with the current course design.

Question 3 is about whether the students find the Business English courses difficult to learn. Fifty-two point two percent of the participants find them difficult to learn, $29.5 \%$ find them not so difficult and $18 \%$ find them difficult to learn.

Question 4-6 try to find the most favored class organization form and the current class organization form. For the current class organization form in Question 4, all the students choose "teachers' explanation in classes", which indicates that the current class organization form is rather simplistic. In Question 5, about 37.7\% of the students prefer expositive teaching conducted by the teacher, with the group discussion, role play and game and other class organization forms followed, the percent being $31.1 \%, 23 \%$ and $8.2 \%$ respectively. From the result, it is concluded that the classical teachers' explanation in classes is still the most favored one. A certain number of students also like other forms like group discussion, role-play and games. Some participants suggest a combination of these forms, which are most advisable for us to organize our classes.

Question 6 is a multiple-choice question, which is designed to find the most favored form of classroom activities. The frequency of counts of the 61 participants is 78 (See Table 1). The number of counts for the item "simulation" is 37, which amounts to almost half of the total counts. As the English used in Business context, simulation can create a valid situation and offer students perceptual material and stimulate their interest of learning Business English.

Table 1. Undergraduates' Most Favored Classroom Activities

\begin{tabular}{cccc}
\hline & \multicolumn{2}{c}{ Responses } & \multirow{2}{*}{ Percent of Cases } \\
\hline Oral Report & $\mathrm{N}$ & Percent & \\
\hline Group discussion & 10 & $12.8 \%$ & $16.4 \%$ \\
\hline Simulation & 16 & $20.5 \%$ & $26.2 \%$ \\
\hline Role play & 37 & $47.4 \%$ & $60.7 \%$ \\
\hline Game & 7 & $9.0 \%$ & $11.5 \%$ \\
\hline Others & 6 & $7.7 \%$ & $9.8 \%$ \\
\hline Total & 2 & $2.6 \%$ & $3.3 \%$ \\
\hline
\end{tabular}

Question 7 is designed to investigate the undergraduates' view on the proportion of Chinese and English used in classes. An overwhelming majority of students (52.5\%) prefer "classes mainly taught in English", $36.1 \%$ of the students choose "bilingual teaching", and about 10\% prefer the teacher to teach all in English in classes. Only one student (1 of 61) choose teaching all in Chinese. An interview with the some of the $52.5 \%$ participants shows that they can hardly concentrate for continuous 2 hours' teaching all in English, and they much like the difficult part explained in Chinese. No one choose "classes taught in Chinese", the reason being that they esteem that language skills can be enhanced during the learning of business courses.

Question 8-10 is about the teaching material used in Business English teaching. Question 8 is "whether you are satisfied with the textbook in use", $65.6 \%$ of the students choose "dissatisfied" and $34.4 \%$ choose satisfied. To find the reasons why students are not satisfied with the textbooks they are using, a multiple choice question is designed in Question 9. The result (as in Table 2) shows that the frequency of counts of the 61 participants is 82 . The number of counts for the item "too theoretical" is 31 , which amounts to $37.8 \%$ of the total counts. The number of counts for item "outdated", "dull" and "lack of interactive exercises" is 14,17 and 20 , which constitute to $17.1 \%, 20.7 \%$ and $24.4 \%$ of the total responses respectively. A closer observation of the results reveals that the textbooks for Business English should be interesting, interactive and practical, which in term may be the guidance for teachers to compile textbooks.

Table 2. Reasons for Students' Dissatisfaction with the Textbooks

\begin{tabular}{lccc}
\hline & \multicolumn{2}{c}{ Responses } & \multirow{2}{*}{ Percent of Cases } \\
\hline Out-dated & $\mathrm{N}$ & Percent & $34.1 \%$ \\
\hline Dull & 14 & $17.1 \%$ & $41.5 \%$ \\
\hline Too theoretical & 17 & $20.7 \%$ & $75.6 \%$ \\
\hline Lack of interactive exercises & 31 & $37.8 \%$ & $48.8 \%$ \\
\hline Total & 20 & $24.4 \%$ & $200 \%$ \\
\hline
\end{tabular}


When asked about what kind of textbook they think is most suitable for Business English learning in question 10, $42.2 \%$ of students prefer the original English edition, and 42.2\% prefer English version with a Chinese translation. $10.9 \%$ like the English book edited by Chinese authors and no one like Chinese-edited textbooks. The original English version books are comparatively more time-effective, authoritative and specialized with fewer print mistakes. Students can improve their language proficiency while learning their professional knowledge. But the English version edition sometimes may be a challenge to some students, especially the business terms which can hardly understand by student even been edited in the Chinese version. This can explain the fact that similar percent of students prefer English version with a Chinese translation, the reason being that the Chinese version can help them understand and master the knowledge and at the same time keep the genuineness of English language.

To find the students' most favored way to learn Business English after class, a multiple-choice question is designed. The frequency of counts of the 61 participants is 77(Table 3). The number of counts for the item "internship" is 38 , which amounts to almost half of the total counts. Then follows the counts for item "extra-curricular reading", "internet" and "lectures" is 21,17 and 1, with the percentage of $27.3 \%, 22.1 \%$ and $1.3 \%$ of the total responses respectively. Internship is believed by the undergraduates as the most effective and acceptable way to learn Business English after class. The features of Business English decide that practical teaching is especially important to Business English teaching.

Table 3. How to Learn Business English after Class

\begin{tabular}{cccc}
\hline & \multicolumn{2}{c}{ Responses } & \multirow{2}{*}{ Percent of Cases } \\
\hline Internet & $\mathrm{N}$ & Percent & \\
\hline Lectures & 17 & $22.1 \%$ & $28.3 \%$ \\
\hline Internship & 1 & $1.3 \%$ & $1.7 \%$ \\
\hline Extra-curricular reading & 38 & $49.4 \%$ & $63.3 \%$ \\
\hline Total & 21 & $27.3 \%$ & $35.0 \%$ \\
\hline
\end{tabular}

Question 12 inquires into which course group is the most proper. The author lists the four modules proposed by the National Curriculum. Module I: English Knowledge and Skills; Module II: English knowledge, business knowledge and business skills; Module III: English knowledge, business knowledge \& skills and cross-cultural communicative competence; Module IV: English knowledge, business knowledge \& skills, cross cultural communicative competence and humanity knowledge. $82 \%$ of the students think the Module IV is most proper, which proves most of the participants agree with the current four course groups.

\subsection{Expectations for Teachers' Qualification}

For the teacher's qualification, about $75.4 \%$ of the participants prefer their teachers to be English Major and have rich experience in Business Teaching. Thirteen students choose "Business-related major and can teach in English, the percentage is 21.3\%"; only 2 students (3.3\%) choose "English major and have some knowledge in business" and none of them choose "business major and can only teach in Chinese". In Business English teaching, students always have high expectations on qualifications of the teachers. In their eyes, a qualified Business English teacher is supposed to be competent both in the language proficiency and business knowledge and skills. The percentage coincides with Ellis and Johnson' point of view, which holds that the first requirement for any Business English trainer is to be an expert in language teaching. In fact, there always exists a contradiction that the language teachers teaching business English do not have the first-hand experiences in business while those with such experiences lack adequate proficiency in teaching the English language. The relevant training of teaching staff is suggested.

\section{Implications and Suggestions}

\subsection{A Clear Defining of the Target Needs}

Business English teachers, Business English teaching institutions should make every possible way to visualize the future career by inviting business practitioners, for example, famous entrepreneurs, graduates to give lectures and this may help the undergraduates have an actual conception of "what they want to do" after they graduate. Business English learners should have a clear view of the target needs before they began their journey of study. Only when target needs is defined, the learning needs can be analyzed. What should be noted is that in defining the target needs, correct life philosophy should be established before their selecting future career. This may be a prerequisite for the Business English learners. They should discard utilitarianism and the wrong attitude of questing quick success and instant benefit in their working position. Handsome salary and higher position can be achieved after years of hardworking.

\subsection{Learning Needs Should be Highlighted}

A well-established language course should well consider the learners' learning needs. The classroom activities, the teaching materials employed, the opportunities and options of out-of-class activities and teachers' knowledge of and attitude to the subject content should all be considered. For the class organizations, a variety of classroom activities should be employed to make the class vivid. As the Business English students will work in business related position such as sourcing, sales, translator or business assistant, simulation is an effective way to motivate them in class to have 
a vivid experience of learning. Besides the traditional expositive teaching, group discussions, role-play, oral report and games should be merged in the Business English classes. Besides, textbooks used in Business English should have a reasonable proportion of English and Chinese that cater to the needs of learner of different levels. Business English teachers should have a good master of language and rich experience. According to Hutchinson \& Waters, the meet of learning needs may make a task enjoyable, fulfilling, manageable, generative etc. (1987). "The project, is guided in terms of its general orientation by the target situation, but its specific content is a response to the learners learning needs."(Hutchinson \& Waters, 1987, p.61)

\subsection{A Balance of the "Four Modules"}

It is advocated by the National Curriculum that the four Modules, namely English knowledge, Business Knowledge \& Skills, Cross Cultural Communicative Competence and Humanity Knowledge are essential part of a Business English curriculum. Universities and colleges of different academic levels and Business English training institutions should investigate the needs of learners and set the proper proportion of these modules. An accurate need may save both time and efforts of teaching institutions and help achieve ideal goal. According to this thesis, cross-cultural communicative competence ability should be further cultivated. As language is the carrier of culture, in the business communication, the failure in language can be understood and neglected, but the cultural failure may be fatal. The cultivation of crosscultural communication should never be neglected and should be put before language and business skills.

\section{Conclusion}

Needs analysis makes a course more focused and closer to the learner needs. Business English teaching institutions should formulate their own curriculum by doing a tactic needs analysis according to the resources available, the learners' motivations and qualities, social environment and place and time of teaching. In the future, the same study can be carried out among a larger pool of Business English learners. Besides, needs analysis can also be conducted from a more comprehensive perspective, graduates, Business English teachers and employers, which will surely offer a holistic and overall reference for the Business English curriculum design.

\section{References}

Brown, J. D. (1995). The elements of language curriculum: A systematic approach to program development. New York: Heinle \& Heinle.

Ellis, M., \& Johnson, C. (2002). Teaching Business English. Shanghai: Shanghai Foreign Language Education Press. Hutchinson, T., \& Waters, A. (1987). English for Specific Purposes. Cambridge: Cambridge University Press.

Li, J. (2011). Curriculum Design for Business English Students Based on Needs Analysis Theory-A Case Study of Shandong Jiaotong University. (Unpublished master's thesis). Shandong Normal University, China.

Pratt, D. (1980). Curriculum design and development. New York: Harcourt Brace Jovanovich. 